\title{
(Dis)quieting the Canon: A Book Review Article of New Work by Fishelov and Papadema, Damrosch, and D'haen
}

\author{
Marta Pacheco Pinto \\ University of Lisbon
}

Follow this and additional works at: https://docs.lib.purdue.edu/clcweb

Part of the Comparative Literature Commons, and the Critical and Cultural Studies Commons

Dedicated to the dissemination of scholarly and professional information, Purdue University Press selects, develops, and distributes quality resources in several key subject areas for which its parent university is famous, including business, technology, health, veterinary medicine, and other selected disciplines in the humanities and sciences.

CLCWeb: Comparative Literature and Culture, the peer-reviewed, full-text, and open-access learned journal in the humanities and social sciences, publishes new scholarship following tenets of the discipline of comparative literature and the field of cultural studies designated as "comparative cultural studies." Publications in the journal are indexed in the Annual Bibliography of English Language and Literature (Chadwyck-Healey), the Arts and Humanities Citation Index (Thomson Reuters ISI), the Humanities Index (Wilson), Humanities International Complete (EBSCO), the International Bibliography of the Modern Language Association of America, and Scopus (Elsevier). The journal is affiliated with the Purdue University Press monograph series of Books in Comparative Cultural Studies. Contact: <clcweb@purdue.edu>

\section{Recommended Citation}

Pacheco Pinto, Marta. "(Dis)quieting the Canon: A Book Review Article of New Work by Fishelov and Papadema, Damrosch, and D'haen." CLCWeb: Comparative Literature and Culture 14.1 (2012): <https://doi.org/10.7771/ 1481-4374.1928>

This text has been double-blind peer reviewed by $2+1$ experts in the field.

The above text, published by Purdue University Press (CPurdue University, has been downloaded 1009 times as of 11/ $07 / 19$.

This document has been made available through Purdue e-Pubs, a service of the Purdue University Libraries. Please contact epubs@purdue.edu for additional information.

This is an Open Access journal. This means that it uses a funding model that does not charge readers or their institutions for access. Readers may freely read, download, copy, distribute, print, search, or link to the full texts of articles. This journal is covered under the CC BY-NC-ND license. 


\title{
PURDUE
}

U N T V E R S T T Y UNIVERSITY PRESS < http://www.thepress.purdue.edu>

\section{CLCWeb: Comparative Literature and Culture}

ISSN 1481-4374 <http://docs.lib.purdue.edu/clcweb> Purdue University Press @Purdue University

CLCWeb: Comparative Literature and Culture, the peer-reviewed, full-text, and open-access learned journal in the humanities and social sciences, publishes new scholarship following tenets of the discipline of comparative literature and the field of cultural studies designated as "comparative cultural studies." In addition to the publication of articles, the journal publishes review articles of scholarly books and publishes research material in its Library Series. Publications in the journal are indexed in the Annual Bibliography of English Language and Literature (Chadwyck-Healey), the Arts and Humanities Citation Index (Thomson Reuters ISI), the Humanities Index (Wilson), Humanities International Complete (EBSCO), the International Bibliography of the Modern Language Association of America, and Scopus (Elsevier). The journal is affiliated with the Purdue University Press monograph series of Books in Comparative Cultural Studies. Contact: <clcweb@purdue.edu>

\author{
Volume 14 Issue 1 (March 2012) Book Review Article 15 \\ Marta Pacheco Pinto, \\ "(Dis)quieting the Canon: \\ A Book Review Article of New Work by Fishelov and Papadema, Damrosch, and D'haen" \\ " <http://docs.lib.purdue.edu/clcweb/vol14/iss1/15>
}

\author{
Contents of CLCWeb: Comparative Literature and Culture 14.1 (2012) \\ <http://docs.lib.purdue.edu/clcweb/vol14/iss1/>
}

\section{Marta PACHECO PINTO}

(Dis)quieting the Canon:

A Book Review Article of New Work by Fishelov and Papadema, Damrosch, and D'haen

David Fishelov's Dialogues with/and Great Books: The Dynamics of Canon Formation (2010) and the collected volume The Canonical Debate Today: Crossing Disciplinary and Cultural Boundaries (Papadima, Damrosch, D'haen, 2011) are books which break new ground on debates surrounding the literary canon and the processes of canon formation.

In Dialogues with/and Great Books Fishelov proposes a dialogic approach to literature as arbiter of literary reputation and consecration and argues that "a work's reputation is an institutionalized result of ... accumulating dialogues" (ix). Although the dialogic approach is not new since Mikhail Bakhtin was introduced by Julia Kristeva to French-language scholarship and after that to Anglophone scholarship in the 1960s and 1980s, respectively, Fishelov takes the dialogic discussion one step further by setting dialogue as a criterion for determining the process of canon formation of a literary work. The most intense debate on this topic goes back to the 1980s and 1990s and it revolved around the reactions to Harold Bloom's The Western Canon: The Books and School of the Ages (1994). Contrary to Bloom who understands the literary canon as a list of books struggling for survival, to put it briefly Fishelov's "great books" label does not restrict itself to books praised for their aesthetic and artistic qualities; instead, his definition of "great" refuses any kind of intrinsic aesthetic valuation and encompasses all kinds of literary works as long as they generate dialogue(s).

Fishelov contends that greatness can be measured against the dialogic relationship a literary work establishes with several systemic categories of the process of canonization, namely readers, authors, translators, adaptors, artists, scholars, and critics. Greatness relies on the correlation between "quantity and diversity" - reformulated throughout the book as "number and variety" and "multitude and heterogeneity" - of the dialogues a work is able to generate. This dialogic perspective gives precedence to the text over the author and to its reception over its production. Thus, Fishelov poses 
two main questions: what is the source of a book's perceived greatness, and how and possibly why do certain books become part of the literary canon? To answer these questions the book is divided into two parts: the first part, titled "What is a Dialogue? What is a Great Book" (chapters 1 to 4), is oriented towards concept definition and mapping; the second part, titled "Some Genuine Dialogues with Great Books" (chapters 5 to 12), complements the previous chapters with specific types of dialogues based on close reading. In the first part of his book Fishelov presents his dialogic approach by putting forward arguments, counterarguments, and a typology of dialogues. These theoretical chapters are evidence of the binarism that structures Fishelov's arguments ("Two Words of Caution" [chapter 1]; "One Table, Two Clarifications" [chapter 2]; "Deciding between the Two Parties" [chapter 3]). In the second part Fishelov illustrates the theoretical framework presented with intersemiotic and interlingual dialogues created by books generally accepted as great.

Chapter 1 ("Real Life Dialogues") begins with the discussion of the key concept of dialogue. It is proposed in preference, but not in opposition, to that of intertextuality, which Fishelov considers too vague with regard to the existing hierarchies between literary texts and the role the author plays in the production of literary greatness. Combining speech act theory with the behaviorist approach, both indebted to Roman Jakobson's model of the communication process, Fishelov identifies constraints (goal, relationship between participants, diction or register, channel or medium), levels of actual interaction (high, relative, minimal), dimensions of verbal interaction (outer and inner, which are respectively linked to form and semantic content), and degrees/scales of participation (passive or active) for the communicative situation. Based on these, Fishelov proposes a descriptive typology of dialogues, which can be defined either as pseudo or genuine. Pseudo-dialogue is divided into echodialogue and dialogue-of-the-deaf. While echo-dialogue defines an asymmetrical verbal exchange where two interlocutors in different positions repeat each other's ideas, dialogue-of-the-deaf occurs when interlocutors expressing different viewpoints fail to actually engage in a listen-respond interaction. On the contrary, genuine dialogues occur when interlocutors are willing to engage in a meaningful exchange of ideas.

Chapter 2 ("Literary Dialogues") shows the affinities between real-life dialogues and literature, and it sets genuine literary dialogues as object of study. Reading is presented as the most traditionally passive form of dialogue (echo-dialogue), alongside translation and adaptation. For these latter forms, the author introduces the concept of "(un)predictability" that is linked to the idea of "inventiveness," as chapter 12 illustrates. What distinguishes then a pseudo-dialogue from a genuine dialogue is the unpredictability of the outcome of a work's rewriting as well as the degree of an author's originality. Translation is thus a case in point: it can range from echo dialogue (e.g., word-for-word or literal translation) to genuine dialogue, when translation adds something to the host system. In other words, the more unpredictable the impact of a dialogue, the more genuine and innovative it is. Fishelov conceives of a dialogic model for translation grounded in the negotiation between the ideal of replication and the ideal of domestication, thus echoing the binary model that has long characterized the discourse on translation in the West.

In Chapter 3 ("The Battle of the [Great] Books") Fishelov defines what a great book is based on a twofold historical perspective: literary greatness is in today's agenda in view of the pace the literary canon has evolved and its openness to more modern and marginal authors. To understand such changes which have shaped the meaning of "a great book," Fishelov revisits the two main traditions which have accounted for canon formation: the beauty party or aesthetic canonicity understood as against the power party or factual-institutional canonicity. To the beauty party the more aesthetic qualities a work evokes, the more the chances of entering the canon of great books. Since the beauty party relies on a criterion of taste considered to be universal, it fails to explain the dynamic and evolving nature of the literary canon. The power party, in turn, fails to explain the stable elements of the canon by focusing on the changing political-ideological dimensions involved in a work's reception. Fishelov contends that these two theoretical stands are to be combined in order to understand what a great book is.

In Chapter 4 ("The Dialogic Approach to Great Books") Fishelov presents data analysis based on up-to-date methods of data collection and ranking, namely internet search engines and online databases, and it requires an attentive reading to grasp the several stages involved in the data collection, ranking, and analysis. It begins by underlining that both quantifiers "many" and "diverse" 
are relative criteria for literary greatness. Each should take into consideration the size of the literary community, the period, medium and means of communication, the literary genre of both the text and its echoes, the heterogeneity of the dialogues generated (intersemiotic, inter-artistic, interlingual), the type of readership, and other context-bound variables. After acknowledging his indebtedness with regard to concept and framework to Hans Robert Jauss and Barbara Herrstein Smith, Fishelov discusses more recent approaches to canon formation (e.g., Damrosch; Murray; Verboord) and begins his dialogic experiment based on the hypothesis that "great books leave traces on different levels of culture" (50). His searches were oriented towards a pre-existing list of works considered great books which occur in three sources: The Norton Anthology of World Masterpieces (Mack, Clinton, Danly, Irele, Knox, Lawall, Nierhorst, Owen, Pasinetti, Viswanathan Peterson), Great Books: My Adventures with Homer, Rousseau, Woolf, and Indestructible Writers of the Western World (Denby) and Masterpieces of World Literature: Plot Summaries, Descriptions of Principal Characters, Critical Evaluations, and the Significance of the Major Works of World Literature (Magill). Those works were then used for the searches Fishelov conducted with four internet search engines. The dialogues those books generate are not only to be quantified based on google searches but also combined with institutional factors which may help speculate about a work's canonical status such as book prizes, literary scandals, and the number of scholarly articles published on a literary work. Therefore, the dialogic approach helps predict literary greatness based on "many different levels of dissemination and reputation," that is, "a work's procreation enhances its reputation" (62).

Fishelov further proposes three main models of dialogic relationship: the tree model, the ponytail model, and the pyramid model. This graphical representation of the dialogic approach is in tune with approaches such as by Siegried J. Schmidt's systemic and empirical approach to literature or Itamar Even-Zohar's polysystem theory - or Franco Moretti's more recent work (see also Villanueva) - and it helps understand the connections highlighted in the second part of the book. The tree model is more suitable to map thematic and structural variations, as chapters 11 and 12 show. The ponytail model illustrates bi-directional flows of meanings, thus accounting for rewritings, interferences, mediations, continuities, and discontinuities which can be traced back to an initiating text (IT). An IT can create several dialoguing texts (DT) which can generate other DTs and themselves become ITs. The pyramid model combines both the tree and the ponytail models. These models are so focused on the connection between an IT and its dialogues that, in my view, they fail to account for such situations as when there is no IT. Such is the case of pseudotranslation, which circulates as a DT and can therefore generate unpredictable dialogues (on this, see, e.g., Toury). This type of fictitious exchange is beyond the scope of the volume, but should encourage a serious follow-up reflection.

The second part of the book consists of case studies. The examples provided are not new and are all retrieved from the Western canon of great books. Although there is no deliberate attempt to defend this canon as paradigmatic, the argument would have gained in widening the scope of examples to non-Western canons. Chapters 5, 6, and 7 set the Bible as the initiating text and give preference to more modern and critical readings, chapters 8,9 , and 10 revisit the Roman classical canon, and chapters 11 and 12 focus on thematic variations. The examples provided also agree on the need to formulate different degrees of predictability based on a work's canonicity (a canonical work will in principle generate more dialogues) and aesthetic value (the more the aesthetic qualities of a work, the more the chances of belonging to the canon of great books), on readers' reaction in reception (scandals will tend to generate more echoes), on forms of echo-dialogues (such as the number of copies, editions and sequels of a work, the number of literary prizes received). Other items for the predictability of canonization are also suggested throughout the volume, such as genre (a successful novel will create more dialogues than a lyrical poem) and topos (the evocation of universal human values readers can relate with will generate more dialogues). In "Concluding Remarks" Fishelov summarizes the main arguments and hypotheses put forward and suggests not only further perspectives and research, but also the possibility of extending the dialogic approach to other forms of art and of associating different genres to specific types of dialogue, which is something the author already attempts to do in parts of the volume (e.g., parody, pantomime, drama as echo-dialogues).

On the whole, Dialogues with/and Great Books is well structured, each chapter concluding with a follow-up to the main points discussed and this helps readers manage the overflow of information in some chapters and refocus the discussion towards the dialogue with/and great books. However, I feel 
that it would have brought greater clarity to the book to explicitly link each example to a specific graphic representation and the date of original publication of some of the literary examples discussed should have been included as well (i.e., Johnson's The Vanity of Human Wishes, Pushkin's "exegi monumentum," Owen's "dulce et decorum est," Diderot's Le Neveu de Rameau, Molière's L'Ecole des femmes, Shaw's Pygmalion). Dialogues with/and Great Books is generally well written, well informed, with a relevant bibliography, and a strong collection of examples either visual or verbal, either microtextual or paratextual which unveil unexpected dialogues. The latter is, to me, one of the assets of the book as it brings in and crosses different types of dialogues illustrated by surprising correlations and comparisons.

The Canonical Debate Today is a collection of articles which offers a wide diversity of critical perspectives on the topic. It brings together articles presented in 2008 at the international conference "National Literatures in the Age of Globalization: The Issue of Canon" at the University of Bucharest. On the one hand, this explains the high number of contributions from Central Europe, in particular from Romania, and the emphasis on Romanian literature and on the need of resituating it within the European literary system. Through the Romanian example, The Canonical Debate Today illustrates a contemporary concern with small or less visible literatures and cultures, especially at a time when attention has riveted to the supranational representation of national cultures. On the other hand, the volume tackles the pace of change in literary and cultural studies by focusing on canon formation and on the shifts, trends, and new directions brought about by globalization. Written from different disciplinary perspectives but through a comparative lens, contributors address other key questions such as what is the canon worth for? What is the place and/or role of small literatures within stronger literary traditions and how to make them more visible? And how to promote canon openness and export national literary traditions beyond national boundaries? In his introduction to the volume Papadima provides a useful overview of the articles included and the topics discussed. He also emphasizes the internal dialogue to the essays, which is self-evident from the overall structure of the book, and refers to the canon as symptomatic of the "inquietude about the fate of literary reading" (16), a less enthusiastic perspective than Fishelov's dialogic approach that evinces the dynamic renewal of literary reading. The volume is divided into three parts: "I. Canons and Contexts," "II. Reshaping Literary Studies," and "III. Transgressing Literary and Cultural Boundaries." Contributors to the first two parts address the topics outlined by means of theoretical discussions and position statements which reassess the canon as an instrument of power, thus providing some of the explanations the dialogic perspective cannot offer. Concepts such as Benedict Anderson's "imagined communities" (1983) and Arjun Appadurai's "imaginary geography" (1996) underlie many of the discussions. The third part includes articles on case studies.

D'haen opens Part I with "How Many Canons Do We Need? World Literature, National Literature, European Literature" and advocates the need of elaborating a European canon as promoter of a collective, cohesive identity, thus revisiting the paradigmatic US-American canon debate that started in the 1920 s and culminated in the 1980s and 1990s. To D'haen "the Europe of the nation states" (31) may have now gathered the same conditions as the United States in the 1990s and is undergoing the same multicultural turn. Education plays a crucial role in this reinvention of European literature, which could begin by examining the US-American anthologies of world literature. Setting the US-American canon as an interpretative frame and the U.S. as both agent and object of globalization from which to rethink the history of canon formation, Rodica Mihăilă also revisits US-American exceptionalism to support a move from multiculturalism to transnationalism in her article "Opening the Boundaries of National Literatures: From a Multicultural to a Transnational Literary Canon. The American Challenge." Such move from multiculturalism as a form of deterritorialization to transnationalism as a relational category of cultural analysis has allowed US-American literature to go global and position itself within/as world literature. In "The Canon Question and the Value of Theory: Towards a New (Non-) Concept of Universality" William Franke revisits context-bound concepts such as value, taste, theory, and value of theory so as to claim the canon's "omniversality," that is, an ongoing, never finished universality thus erasing borders of time and space. Omniversality emphasizes the literary canon as an inclusive and transhistorical process of value revision which shows how values can become universal. Caius Dobrescu's "European Literary Canon-Building as Federalist Phenomenology" takes the value issue further by focusing on the European literary canon as manifestation of Europeanness 
and by proposing, in line with D'haen, canon planning as trust building oriented towards the phenomenological perception of "value-as-experience," which echoes Franke's "omniversality." The author shows that Europeanness can best be perceived from an alien gaze, thus describing a threefold category of authors whose experience from the outside could build Europe as a homogeneous whole. In "What to Do about Constructing the Literary Canon: Canonicity and Canonical Criteria" Delia Ungureanu underlines the usefulness of the canon based on a well-structured sketch of the main theoretical and critical trends in the 1990s and 2000s in response to Bloom's anti-multiculturalist and aesthetics oriented view of the literary work. Adina Ciugureanu's "From Art to Literature: Towards a Counter-Canonical Canon?" accounts for the semantic evolution of the term "canon" from the visual arts to literature by drawing chiefly on Foucault and Bloom. Originally at the basis of Egyptian art and its fixed patterns of proportion, symmetry, and beauty, it would suffer deviations from the aesthetic norm in search of new patterns of perfection. Each new attempt at improving the canon would allow for the rise of counter-canons, thus showing that the canon dynamics relies on the constant challenge of the different canons accepted at a given historical moment in the different arts. In "Episteme and Literary Canon: A Parallel between Michel Foucault and Harold Bloom" Simona Drăgan equates Foucault's theory of the "episteme" - which refers to the possibility of scientific knowledge - with Bloom's conception of the "canon" - which pertains to the realm of literature and is applied in support of the idea of "great books." Drăgan parallels historical periods into which both concepts are divided, argues for complementariness, and concludes in favor of the reliability of the literary canon. Zakaria Fatih addresses in "The Literary Canon and its Religious Precursor" the importation of the canon from religion into literary studies and contends that the intrinsic relationship between religion and literature has always been at the heart of dynamics in canon formation. Special emphasis is given to Northrop Frye, and Fatih's discussion revolves around the definition of a classic (e.g., Sainte-Beuve, Eliot), which holds the status of a sacred text. In "Against the Canon: Jean Cocteau or the Rise of the Gay Cultural Icon" Frédéric Canovas offers an insight from queer studies which sets Jean Cocteau as the first representative of the literary canon of homosexuality: Cocteau's evolving counterdiscourse on gender performance is analyzed in opposition to that of more central nineteenth-century French writers, particularly André Gide and Marcel Proust. Magda Răduţă concludes Part I highlighting the strong link between literary canon and shifts in political regimes in "The Day Before, the Day After: Canonic and Self-Legitimation Changes in the Romanian Literature Before and After the Fall of the Communist Regime." Departing from a sociologically oriented approach, the evolution of the Romanian literary field is analyzed based on writers' perception of themselves and the literary struggle for power before and after the collapse of communism in Romania in 1989.

Part II is more discipline oriented. It includes five contributions looking retrospectively into the impact of globalization as an engine of change and into the multiculturalism it has brought along, discussing the readjustment of the discipline of comparative literature to that of global turn. How American is the American view of world literature? Curiously, throughout the volume contributors tend to prefer "American" when referring to the U.S., thus unaware of the hegemonic appropriation of the continent to the U.S. (on this, see, e.g., McClennen; Kadir). The question about US-American literature is what Damrosch tries to answer in "Comparative World Literature" by revisiting the history of comparative literature in the United States and by setting its institutional background and curricula against the national focus of the comparatist practice in India and China. Damrosch promotes world literature as an emerging world macro-system which feeds on the negotiation between an inward and an outward movement based on a decentered approach to the world's literary traditions and highlights the need of studying different comparatist approaches to world literature as a means of widening the comparatist perspective (on the recent development of the concept of world literature, see., e.g., Damrosch; D'haen; D'haen, Damrosch, Kadir; D'haen, Domínguez, Rosendahl Thomsen; Rosendahl Thomsen; on comparative literature as a global discipline conceived as comparative cultural studies, see Tötösy de Zepetnek and Mukherjee). Both Dumitru Radu Popa and Oana Fotache draw on Damrosch's concept of world literature as a mode of circulation and reading that has helped to cope with globalization. In "Globalization and Comparative Literature Revisited: An Analytical Survey" Popa lists several definitions of the catchword "globalization" and considers its impact on national literatures. World literature is presented as a rather optimistic change from comparative literature and as a space where third world literature can gain visibility. Bringing in discussions of (im)migrant 
writing and pop culture, Oana Fotache, in her article "'Global Literature': In Search of a Definition," opposes the concept of world literature as past oriented and engaging directly with canon formation to "global literature" which, in turn, is presented as a specific present oriented attitude that engages directly with general readership and does not aim to collect all national literatures (on another view and critical of the concept of world literature, see, e.g., Figueira). Mihaela Irimia, in her article "The Classic Modern Canon and the Disciplinary Separation," discusses the disciplinary institutionalization of literature before the global turn and investigates the keywords "literary history," "modernity," and "classic modernity" as well as "beauty" and "correctness" as yardsticks linked to the evolving concept of taste. In this vein, Stefan H. Uhlig's "Historiography or Rhetoric? A Road (Not) Taken in the Evolution of the Literary Field" is with focus on the nineteenth-century institutionalization of literature by intertwining literary historiography (literature and literary history) with historical rhetoric (rhetoric and belles lettres). Literature as a conceptual and historical legacy which brings together heterogeneous textual archives could help understand present changes to literary studies brought about by globalization.

In Part III eight case studies are presented, drawn mostly from the Romanian literary canon. Elaine Martin and Ion Manolescu highlight the binarisms on which the canon is grounded high/superior and low/inferior, past/present, local/global, inclusive/exclusive, classic/popular, text/image, minor/major genres. In "'Ceci tuera cela?': Literary Canons and the Challenge of Visual Imagery and Popular Culture," Martin goes into the recent field of intermedia studies and links the prevalence of image media over text media (the graphic novel is a case in point) and the change in reading habits to the dissolution of boundaries between pop and high culture (on intermediality, see also Tötösy de Zepetnek, López-Varela Azcárate, Saussy, Mieszkowski). In "Popular Culture and the Romanian Postmodernist Canon: The Case of Comics' Authors" Manolescu focuses on the comics genre traditionally disregarded by the literary canon. The author uses the phrase "canonic calibration" (250) to refer to such mechanisms as encyclopaedias, literary anthologies, textbooks that help in/form the canon and acknowledge its blindness to popular literature (on this, see also, e.g., Vandermeersche). In "National versus World Literature Seen as a Confrontation between Modernism and Balkanism" Alexandra Vrânceanu puts forward an interesting case study on two Romanian intellectuals who are in reverse positions in relation to the Romanian national canon and the European literary canon in view of the different values each promoted. Vrânceanu shows that literary canons are ideology bound because individual authors will only be assimilated into mainstream canons if they comply with the latter's trends. Ileana Orlich continues discussing Romanian modernism but in connection with the crisis of masculinity as symptomatic of a wider crisis of the human being. In "Modernism and the Male World: The Crisis of Masculinity in The Bed of Procrustes" Orlich offers a psychoanalytical reading of Camil Petrescu's 1933 novel from the perspective of male hysteria and homosocial bonding. Roumiana L. Stantcheva and Cristina Balinte expand on how comparativist practice has adapted to globalization and made room for small literatures to participate in the world's literary dialogue. In "To Label, to Compare, to Appropriate... As a Strategy of Foreign Literary Criticism" Stantcheva focuses on literary criticism and scholarship as an increasingly "glocalized" practice and comments on the gains and losses of the comparativist strategies followed by literary critics and scholars from more central cultures and who tend to appropriate texts from more peripheral literatures by seeking familiar and prestigious points of reference. Balinte's "National Enlisting/European Rallying: Access Criteria to the Continental Space for Romanian Literature" is about how to promote literary image of less known cultures to put an end to what she terms "an elusive Europe complex." Balinte proposes finding affinities between those cultures and more central literatures so as to easily export them. Realizing that ideology precedes aesthetics, Balinte concludes in the same vein as Vrânceanu, that is, the need of domestically promoting distinctive national literary features which conform to outside general expectations. Iona Both and Mădălina Vatcu relate canon formation with translatability and translation strategies. In "A Romanian Product Refused for Export: Mihai Eminescu, National Poet" Both draws on the example of Eminescu to address three questions: how translatable is the poet's language, how well does the idea of a "national author" travel, and how ready are scholars to change their strategies to export authors? Finally, Vatcu in "Openings of the Romanian Poetry Anthologies Translated into French: Canonical Variations during the Communist Period" expands on translated anthologies as a selected contribution to canon formation. Vatcu contends that instead of emphasizing the canonical 
character of an anthology, further attention such be given to the provisional nature of criteria in anthologizing. All articles in The Canonical Debate Today define canon as an ongoing and inclusive process in need of constant renewal. It is thus to be underlined the use of spatial concepts and metaphors such as geography, boundary, center, periphery, national, global which emphasize literature as the circulation of literary capital and the role canon can play in regulating that circulation. What strikes me is the overall attempt of each contributor to the volume to provide solutions for the restraining effects of the canon. The general use of the modal "should" illustrates such attempt.

In conclusion, the two volumes reviewed show that the dynamics of canon formation not only relies on a dialogue between past, present, and future, but also poses a question of scale: Dialogues with/and Great Books determines quantity and variety as criteria for describing a work as "great" while The Canonical Debate Today dwells on globalization and world literature as levers to reshape literary studies in order to reconcile the tension between global/supranational and local/national. Both books are recommended reading for scholars and students in the fields of literary studies, world literature, comparative literature, translation studies, literary theory, reception studies, anthology studies, as well as media studies.

\section{Works Cited}

Anderson, Benedict. Imagined Communities: Reflections on the Origin and Spread of Nationalism. London: Verso, 1983.

Appadurai, Arjun. Modernity at Large: Cultural Dimensions of Globalization. Minneapolis: U of Minnesota P, 1996.

Bloom, Harold. The Western Canon: The Books and School of the Ages. New York: Penguin, 1995.

Damrosch, David. "World Literature in a Postcanonical, Hypercanonical Age." Comparative Literature in an Age of Globalization. Ed. Haun Saussy. Baltimore: The Johns Hopkins UP, 2006. 43-53.

Damrosch, David. What is World Literature? Princeton: Princeton UP, 2003.

Denby, David. Great Books: My Adventures with Homer, Rousseau, Woolf, and Indestructible Writers of the Western World. New York: Simon \& Schuster, 1996.

D'haen, Theo. The Routledge Concise History of World Literature. London: Routledge, 2011.

D'haen, Theo, David Damrosch, and Djelal Kadir, eds. The Routledge Companion to World Literature. London: Routledge, 2012.

D'haen, Theo, César Domínguez, and Mads Rosendahl Thomsen, eds. World Literature: A Reader. London: Routledge, 2012.

Even-Zohar, Itamar. "Factors and Dependencies of Culture: A Revised Outline for Polysystem Culture Research." Canadian Review of Comparative Literature / Revue Canadienne de Littérature Comparée 24.1 (1997): 15-34.

Even-Zohar, Itamar. Polysystem Studies. Special Issue Poetics Today 11.1 (1990): 1-268.

Figueira, Dorothy M. "Comparative Literature versus World Literature." The Comparatist 34 (2010): 29-36.

Fishelov, David. Dialogues with/and Great Books: The Dynamics of Canon Formation. Brighton: Sussex Academic P, 2010.

Jauss, Hans Robert. Toward an Aesthetic Reception. Trans. Timothy Bahti. Minneapolis: U of Minnesota P, 1982.

Kadir, Djelal. "Concentric Hemispheres: American Studies and Comparative Literature." Trans/American, Trans/Oceanic, Trans/lation: Issues in International American Studies. Ed. Susana Araújo, João Ferreira Duarte, and Marta Pacheco Pinto. Newcastle upon Tyne: Cambridge Scholars Publishing, 2010. 27-37.

Kristeva, Julia. "Bakhtine, le mot, le dialogue et le roman." Critique 23 (1967): 438-65.

Kristeva, Julia. Desire in Language: A Semiotic Approach to Literature and Art. Trans. Thomas Gora and Alice Jardine.Ed. Leon S. Roudiez. Oxford: Blackwell, 1981.

Mack, Maynard, Jerome W. Clinton, Robert Lyons Danly, Francis Abiola Irele, Bernard Knox, Sarah Lawall, John Nierhorst, Stephen Owen, P.M. Pasinetti, and Indira Viswanathan Peterson, eds. The Norton Anthology of World Masterpieces. New York: Norton, 1997.

Magill, Frank N. Masterpieces of World Literature: Plot Summaries, Descriptions of Principal Characters, Critical Evaluations, and the Significance of the Major Works of World Literature. New York: HarperCollins, 1991.

McClennen, Sophia A. "Inter-American Studies or Imperial American Studies?" Comparative American Studies: An International Journal 3.4 (2005): 393-414.

Moretti, Franco. Graphs, Maps, Trees: Abstract Models for a Literary History. London: Verso, 2005.

Murray, Charles. Human Accomplishment: The Pursuit of Excellence in the Arts and Sciences, 800 BC to 1950 . New York: HarperCollins, 2003.

Papadima, Liviu, David Damrosch, and Theo D'haen, eds. The Canonical Debate Today: Crossing Disciplinary and Cultural Boundaries. Amsterdam: Rodopi, 2011.

Rosendahl Thomsen, Mads. Mapping World Literature: International Canonization and Transnational Literatures. London: Continuum, 2010.

Schmidt, Siegfried J. Foundations for the Empirical Study of Literature: The Components of a Basic Theory. Trans. Robert de Beaugrande. Hamburg: Buske, 1982.

Schmidt, Siegfried J. "Literary Studies from Hermeneutics to Media Culture Studies." CLCWeb: Comparative Literature and Culture 12.1 (2010): <http://docs.lib.purdue.edu/clcweb/vol12/iss1/1/>.

Smith Herrnstein, Barbara. Contingencies of Value: Alternative Perspectives for Critical Theory. Cambridge: Harvard UP, 1988. 
Marta Pacheco Pinto, "(Dis)quieting the Canon:

A Book Review Article of New Work by Fishelov and Papadema, Damrosch, and D'haen"

page 8 of 8

CLCWeb: Comparative Literature and Culture 14.1 (2012): <http://docs.lib.purdue.edu/clcweb/vol14/iss1/15>

Tötösy de Zepetnek, Steven, and Tutun Mukherjee, eds. The Cambridge Companion to Comparative Literature and Comparative Cultural Studies. Cambridge: Cambridge UP, 2012. Forthcoming.

Tötösy de Zepetnek, Steven, Asunción López-Varela Azcárate, Haun Saussy, and Jan Mieszkowski, eds. New Perspectives on Material Culture and Intermedial Practice. Thematic Issue CLCWeb: Comparative Literature and Culture 13.3 (2011): <http://docs.lib.purdue.edu/clcweb/vol13/iss3/>.

Toury, Gideon. "Pseudotranslations and Their Significance." Descriptive Translation Studies and Beyond. Amsterdam: John Benjamins, 1995. 40-52.

Toury, Gideon. "Translation, Literary Translation and Pseudotranslation." Comparative Criticism 6 (1984): 73-85.

Vandermeersche, Geert, and Ronald Soetaert. "Intermediality as Cultural Literacy and Teaching the Graphic Novel." CLCWeb: Comparative Literature and Culture 13.3 (2011): <http://docs.lib.purdue.edu/clcweb/vol13/iss3/20>.

Verboord, Marc. "Classification of Authors by Literary Prestige." Poetics 31 (2003): 259-82.

Villanueva, Darío. "Possibilities and Limits of Comparative Literature Today." CLCWeb: Comparative Literature and Culture 13.5 (2011): <http://docs.lib.purdue.edu/clcweb/vol13/iss5/2>.

Reviewer's profile: Marta Pacheco Pinto is working towards her doctorate with a dissertation entitled Translating the Oriental Other: The Configuration of the Female Figure in Turn-of-the-Century Portuguese Literature (António Feijó and Wenceslau de Moraes) at the University of Lisbon. Pacheco Pinto's recent publications include the collected volumes Trans/American, Trans/Oceanic, Trans/lation: Issues in International American Studies (Ed. Susana Araújo, João Ferreira Duarte, and Marta Pacheco Pinto, 2010) and Macau na escrita, escritas de Macau (Ed. Ana Paula Laborinho and Marta Pacheco Pinto, 2010). E-mail: <egma@sapo.pt> 